\title{
Teologia wypowiedzi Jezusa z krzyża
}

Przedstawiony temat skupia uwagę na zdaniach, które Pan Jezus wypowiedział z wysokości krzyża. Są to sentencje szczególnie istotne, gdyż wyraził je Mistrz z Nazaretu w przeciągu ostatnich godzin swojego życia - pomiędzy ukrzyżowaniem a godziną swej śmierci. Tradycja mówi o siedmiu sentencjach Jezusa z krzyża zawartych w Ewangeliach. Wiadomo, że każdy z ewangelistów poświęca w swoim dziele wiele uwagi temu tematowi, prezentując dramat umierania Chrystusa w kontekście swojego własnego ujęcia teologicznego. Interesujący jest fakt, że ewangeliści Marek i Mateusz mówią tylko o jednym zdaniu Jezusa z krzyża (Mk 15, 34 i Mt 27, 46). Stwierdzają oni (Mk 15, 37 i Mt 27, 50), że Mistrz

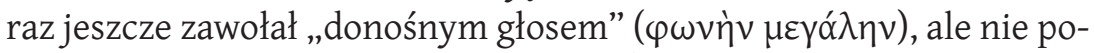
dają tekstu tego powtórnego okrzyku. Święty Łukasz zanotował trzy wypowiedzi z krzyża, ale nie zapisał tej, którą mają Mk i Mt. Wyraźnie zatem w swojej prezentacji teologicznej ukrzyżowanego Jezusa zdobywa się na dużą autonomię ${ }^{1}$. Sentencje Ewangelii według św. Łukasza to: 23, 34. 43 i 46. Święty Jan Ewangelista ma również trzy wypowiedzi: J 19, 25-27. 28 i 30, ale tutaj dotykamy wyjątkowego świadectwa słowa, gdyż Jan był naocznym świadkiem męki i śmierci Jezusa na krzyżu i słyszał owe wypowiedzi umierającego Mistrza.

Bazę biblijną dla prowadzonych analiz stanowić będzie opracowanie znanego polskiego biblisty o. prof. Hugolina Langkammera: Passio Domini nostri Jezu Christi. Nowy Testament o męce i śmierci Jezusa², gdzie są

${ }^{1}$ Dziś przyjmuje się na ogół, że Łukasz znał tekst Ewangelii według św. Marka - por. S. Gądecki, Wstęp do Ewangelii Synoptycznych, Gniezno 1992, s. 153.

${ }^{2}$ Por. H. Langkammer, Passio Domini nostriJezu Christi. Nowy Testament o męce i śmierci Jezusa, Wrocław 1994, s. 104-116. 
przybliżone te słowa Mistrza. Jeśli chodzi o autentyczność ostatnich słów Jezusa, to nie budzą one w zasadzie dyskusji egzegetycznych, zatem możemy ze spokojem przyjąć ich rzeczywistość. Nie ma kontrowersji wśród uczonych także w kwestii ich kolejności. W niniejszym jednak artykule nie pójdziemy drogą tradycyjnego uporządkowania kolejności wypowiadania się Jezusa z krzyża, ale drogą relacji tychże wypowiedzi: do kogo i co Jezus mówił z krzyża?

Zasadniczo wypowiedzi Jezusa z krzyża ogniskują się w trzech ujęciach: do Ojca, do ludzi, którzy znajdowali się w pobliżu krzyża, oraz do siebie (tzw. „,autosentencje”).

\section{Jezus z krzyża modli się do Ojca}

Spośród siedmiu wypowiedzi, które zanotowały Ewangelie, trzy odnoszą się bezpośrednio do Boga Ojca: Łk 23, 34; Mt 27, 46 i Łk 23, 56. Można spojrzeć na te trzy zdania Chrystusa w rozumieniu modlitwy: za wrogów, ufności oraz agonalnej.

\section{Modlitwa za prześladowców Jezusa}

Biorąc pod uwagę czas i przestrzeń ostatnich momentów życia Jezusa, ewangelista Łukasz notuje, że: „Gdy przyszli na miejsce, zwane «Czaszką», ukrzyżowali tam Jego i złoczyńców, jednego po prawej, drugiego po lewej Jego stronie" (Łk 23, 33). Miejsce wykonania wyroku na Mistrzu z Nazaretu jest tu określone precyzyjnie jako miejsce Czaszki

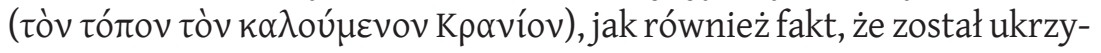

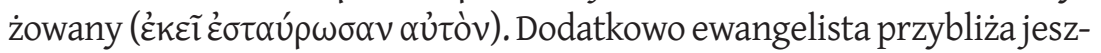

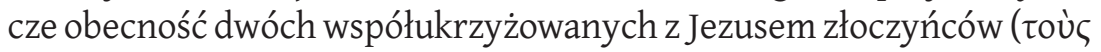
kakoúpyouc). Sceneria tego wydarzenia odmalowana jest w wyjątkowo barwnych emocjonalnie terminach. Stanowi to doskonałe wprowadzenie do pierwszej wypowiedzi Jezusa, kiedy już zawisł przygwożdżony ${ }^{3}$ do krzyża pośród dwóch innych ludzi. Cierpienie Pana przybitego do

${ }^{3}$ Interesujące jest to, że hagiograf nie wypowiada się na temat sposobu przytwierdzenia Jezusowego ciała do drzewa krzyża w opisie krzyżowania. Mówi natomiast już po zmartwychwstaniu Pana o miejscach po gwoździach w rękach Jezusa, których pragnie dotknąć Tomasz (J 20, 25) - zob. B. Zbroja, Znaczenie terminów własnych Ewangelii św. Jana dla jej teologii, Kraków 2002. 
drzewa owocuje jednak nie jękiem bólu ani złorzeczenia na oprawców, ale pierwszą wypowiedzią, która jest modlitwą błagalną zwróconą do Ojca za tych, którzy zadali Mu to cierpienie. Jezus mówi w kierunku Boga: „Ojcze, przebacz im, bo nie wiedzą, co czynią" (Łk 23, 34). Wypowiedź ta umieszczona jest pomiędzy faktem ukrzyżowania Jezusa a rozdzielenia należących do Niego szat (w. 34). Jezus z wysokości krzyża modli się za złoczyńców, którzy zadali mu potworny i śmiercionośny ból, prosząc Boga najbardziej skutecznym określeniem modlitewnym: „Ojcze” ( $\pi \alpha ́ \tau \varepsilon \rho)$. W wielu miejscach Ewangelii Jezus zwraca się do Boga tym określeniem, uznając się w pełni za Jego naturalnego Syna ${ }^{4}$. Ta wypowiedź modlitwy z pewnością jest wysłuchana przez Boga, gdy cierpiący Jezus prosi o darowanie ludziom krzywdy Mu wyrządzonej: „odpuść

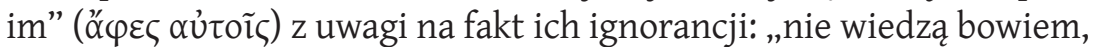

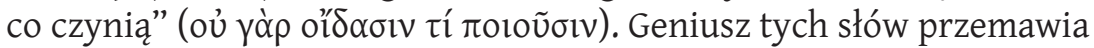
jeszcze dobitniej, gdy zauważymy formę wypowiedzi św. Łukasza, który stosuje tutaj odpowiednio dobrane czasy. Trzy czasy: aoryst, perfektum oraz prezens użyte są w każdym z trzech czasowników: „odpuść”

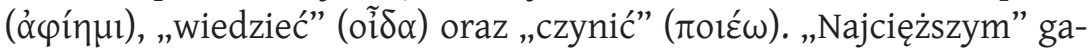
tunkowo z tych trzech jest z pewnością określenie zapisane w czasie perfektum: oủ oídaolv („nie wiedzą"), które rozumiemy jako czynność, która miała miejsce w przeszłości, a której skutki są obecne aktualnie: nie rozpoznali, nie zrozumieli, są w ignorancji i dlatego teraz tak się zachowują, gdyż nie mają wymaganej świadomości. Pamiętać należy ważne stwierdzenie o Jezusie: „nie potrzebował niczyjego świadectwa o człowieku. Sam bowiem wiedział, co w człowieku się kryje" (J 2, 25), które potwierdza szczerość Chrystusowej modlitwy za prześladujących. Jezus po prostu wie, że oni nie wiedzą - nie zdają sobie sprawy z tego, co czynią, i właśnie na to zwraca uwagę swego Ojca, prosząc, aby im wybaczył dokonaną na Nim zbrodnię. Czasownik ớ $\varphi \varepsilon \varsigma$ posiada formę aorystu, który w imperatiwie wyraża rozkaz, usilną prośbę dotyczącą konkretnej, jednorazowej sytuacji. Umierając na krzyżu, Jezus prosi Boga, aby wybaczył Jego oprawcom. Modlitwę tę spowodowało właśnie

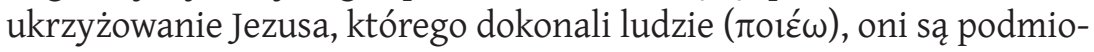
tem tego konkretnego działania. Jak jednak zauważyliśmy, owa akcja

\footnotetext{
${ }^{4}$ Por. Katechizm Kościoła Katolickiego, Poznań² 2002, nr 454.
} 
spowodowana jest ignorancją ludzi. Nie w pełni świadomie uczynili oni to, co widzimy w Ewangelii. Jednakże Jezus modli się za nich, prosząc o odpuszczenie. Zatem nie jest to czyn, który nie wiąże się z żadnymi konsekwencjami moralnymi dla człowieka. Widać tu wyraźnie ważną myśl Ewangelii, że niekiedy nawet niewiedza nie zwalnia człowieka z odpowiedzialności za popełnione czyny, które w osądzie Jezusa domagają się modlitwy przebłagalnej i Jego ofiary krzyżowej.

\section{Modlitwa zawierzenia}

Druga sentencja odnosząca się do Boga, którą wypowiedział Pan Jezus z wysokości krzyża, koncentruje się na modlitwie zaczerpniętej z Psalmu 22 (21). Ewangelista Marek zapisał te słowa Jezusa w formie: „Eloi, Eloi, lema sabachthani” (Mk 15, 34), natomiast Mateusz w formie: „Eli, Eli, lema sabachthani” (Mt 27, 46), które od razu obydwaj tłuma-

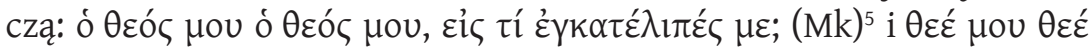

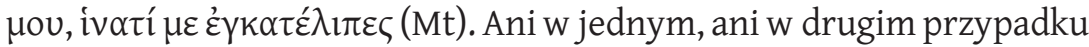
wersja Septuaginty ${ }^{6}$ nie może stanowić bezpośredniej bazy dla słów Ewangelistów, gdyż w języku greckim werset psalmu brzmi następu-

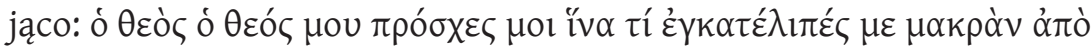

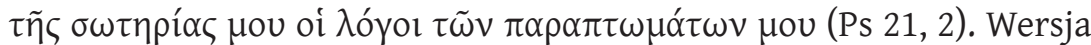

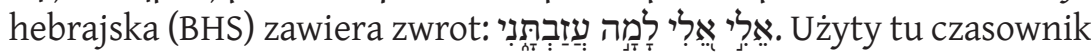
עָזָ rozumiemy jako „zostawić, zapomnieć, utracić”7. Także więc i wersja hebrajska nie do końca precyzyjnie jest tutaj bazą dla hagiografów Nowego Testamentu. J. Homerski ${ }^{8}$ widzi tutaj połączenie zwrotu hebrajskiego („Boże mój, Boże mój”) z aramejskim („czemuś mnie opuścił”). Psalm 22 (21) jest zapisany w formie lamentacji, w której podmiot wypowiada modlitwę błagalną do Boga powodowany złem ze strony przeciwników

${ }^{5}$ Por. Ewangelia według św. Marka, wstęp, przekł. z oryginału, komentarz oprac. H. Langkammer, Poznań-Warszawa 2007, s. 348-349 (Pismo Święte Nowego Testamentu, 3.2).

${ }^{6}$ Por. Septuaginta. Id est Vetus Testamentum graece iuxta LXX interpretes, edidit A. Rahlfs, t. 1-2, Stuttgart $1979^{8}$.

${ }^{7}$ Por. P. Briks, Podręczny słownik hebrajsko-polski i aramejsko-polski Starego Testamentu, Warszawa $2000^{3}$, s. 256.

${ }^{8}$ Por. Ewangelia według św. Mateusza, wstęp, przekł. z oryginału, komentarz oprac. J. Homerski, Poznań-Warszawa 1979, s. 352 (Pismo Święte Nowego Testamentu, 3.1). 
swojego zbawienia9. Słowa tu wypowiedziane prezentują ogrom uczuć bohatera, który pomimo niebywałej męki nie traci nigdy z horyzontu obecności Boga ${ }^{10}$.Zdaniem J. Homerskiego można by odnieść na pierwszy rzut oka wrażenie, że Jezus został opuszczony przez Boga i pogrążył się w ludzkiej beznadziejności, jednakże idzie tutaj ewangelistom (Mk i Mt) nade wszystko o zaakcentowanie ogromnego dramatu sytuacji, którą przeżywa Mesjasz na krzyżu oraz Jego niezachwianej ufności wyrażonej właśnie w słowach modlitwy biblijnej - tekstem Psalmu 22 (21) ${ }^{11}$. Wydaje się, że Bóg Go jakby opuścił, ale modlący się Jezus wypowiada słowa nie do kogoś innego, ale właśnie do Ojca!

Wypada zaakcentować tu jeszcze jeden element, a mianowicie fakt, że sentencja psalmu, którą Jezus wypowiada, pochodzi z Jego pamięci. W tak dramatycznym momencie, jaki opisują Mk i Mt, Mistrz skupia swoją uwagę nie tyle na własnym cierpieniu czy na swoich wrogach, ale na Ojcu i na Jego słowie zawartym w tekście Biblii. Pamięć Jezusa służy prezentacji doskonałości, którą może osiągnąć człowiek idący za wzorem Mistrza z Nazaretu.

\section{"Ostatnia" modlitwa Jezusa}

Najbardziej kluczowymi słowami zdają się być te, które Jezus wypowiedział z wysokości krzyża jako ostatnie: „Ojcze, w Twoje ręce powierzam ducha mojego" (Łk 23, 46), po wypowiedzeniu których, według

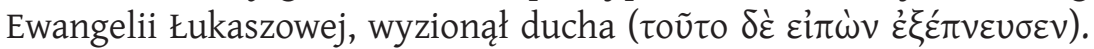
Owo poprzedzone prośbą oddanie ducha w opiekę Ojca stanowi mocne zakończenie w pełni świadomego umierania Mistrza z Nazaretu. Do swego ostatniego tchnienia jest On zjednoczony z Bogiem. Poprzedzające słowa ewangelisty Łukasza zwracają uwagę na niezwykłe wydarzenia, które towarzyszyły umierającemu Jezusowi. Najpierw jest to obraz ciemności (бKótoৎ), które ogarnęły ziemię od godziny szóstej aż do

${ }^{9}$ Por. Księga Psalmów, wstęp, przekład z oryginału, komentarz, ekskursy oprac. S. Łach, Poznań 1990, s. 174 (Pismo Święte Starego Testamentu, 7.2).

${ }^{10}$ Por. Ewangelia według świętego Mateusza. Cz. 2: Rozdziały 14-28, wstęp, przekład z oryginału, komentarz A. Paciorek, Częstochowa 2008, s. 667.

${ }^{11}$ Por. Ewangelia według św. Mateusza, dz. cyt., s. 352-353. Podobnie wyjaśnia to S. Gądecki, Wstęp do Ewangelii synoptycznych, dz. cyt., s. 274. 
dziewiątej (Łk 23, 44) $)^{12}$. Hagiograf wspomina tutaj (w. 45) również o za-

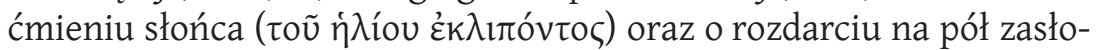

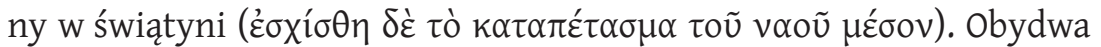

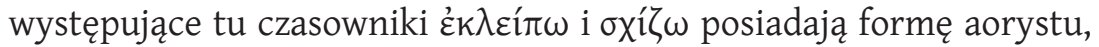
pierwszy w imiesłowie, drugi zaś w indikatiwie. W aoryście jest również zanotowane działanie Jezusa, które stanowi wydanie z siebie głośne-

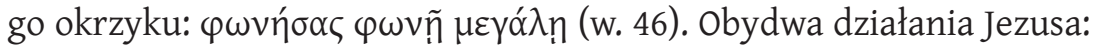
wydanie donośnego krzyku i oddanie ducha w opiekę Ojca są zapisane w stronie czynnej w aoryście, pierwszy w formie imiesłowu, a drugi w indikatiwie. Mistrz z Nazaretu zdaniem H. Langkammera ${ }^{13}$ wypowiada w tym momencie znów słowa Biblii, a konkretnie fragment Psalmu 31 (30), 6, w którym bohater niewinnie prześladowany przez wrogów

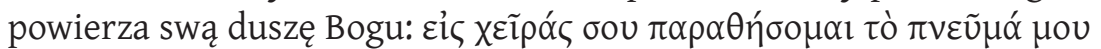
(LXX). Trzeba zwrócić uwagę na nieco odmienną formę w wersji LXX i Łukasza. Grecki Stary Testament na czynność powierzenia duszy wybawicielowi używa formy $\pi \alpha \rho \alpha \theta \eta ́ \sigma o \mu \alpha$, natomiast św. Łukasz stosuje formę $\pi \alpha \rho \alpha \tau i ́ \theta \varepsilon \mu \alpha$ l. Ewangelista używa tu czasu prezens, zaś LXX czasu futurum. To, co zatem zapowiada tekst Psałterza (przyszłość dla czasów Starego Testamentu), Jezus czyni faktem (teraz dla czasów Nowego Testamentu), oddając swego ducha w opiekę Ojca.

Zauważyliśmy, jak się wydaje, ważne przesłanie wypowiedzi Jezusa z krzyża, których celem jest Bóg Ojciec. Prośba za prześladujących Go, którzy nie są w pełni świadomi swojego działania połączona ze słowami modlitwy z Psałterza prezentują mistrzowskie zachowanie się Jezusa także w ostatnim momencie aktualnego eonu. Psalmy 22 (21) i 31 (30) doskonale współbrzmią z duchem Jezusowej Ewangelii. Modlitwa słowami Pisma w momencie tak dramatycznym oraz całkowite zawierzenie w ostatnim akordzie istnienia ziemskiego stanowią Chrystusowy model życia i umierania.

${ }^{12}$ Było to pomiędzy południem a godziną piętnastą - por. K. Romaniuk, A. Jankowski, L. Stachowiak, Komentarz praktyczny do Nowego Testamentu, t. 1, Poznań-Kraków 1999, s. 407.

${ }^{13}$ Por. H. Langkammer, Passio Domini nostri Jezu Christi..., dz. cyt., s. 114. 
Słowa Jezusa z krzyża wypowiedziane do życzliwych Mu ludzi

Drugim elementem naszych analiz uczynimy dwa teksty, w których Jezus zwraca się nie bezpośrednio do Ojca, ale do konkretnych ludzi, którzy uczynili swoim miejsce w pobliżu Jego krzyża. Warto zauważyć, że jest tutaj mowa o trzech osobach: Maryi, umiłowanym uczniu (J 19, 25-27) i skruszonym złoczyńcy (Łk 23, 43).

Słowa nadziei dla pokutującego złoczyńcy

Tylko św. Łukasz zapisał dialog pomiędzy Jezusem i wiszącym obok złoczyńcą, który przed drugim zaświadczył o niewinności Chrystusa.Jak notuje hagiograf, jeden ze złoczyńców bluźnił ( $\dot{\beta} \lambda \alpha \sigma \varphi \eta ́ \mu \varepsilon \imath)$ Jezusowi: „Czy Ty nie jesteś Mesjaszem? Wybaw więc siebie i nas" (oủxì où zĩ

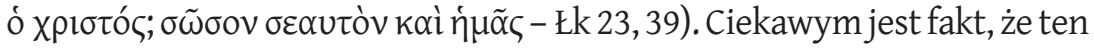
człowiek, który ponosił karę ukrzyżowania, zdobywa się na złorzeczenie wobec współtowarzysza męki - Jezusa. Autor natchniony pokazuje przez to wyraźnie, że w każdym położeniu człowieka, nawet w największym dramacie, gdy Bóg jest niejako najbliżej ludzi, wolna w wyborze i decydowaniu istota ludzka jest w stanie odrzucić solidarną bliskość Pana. W cierpieniu czy w umieraniu człowiek, jak to tutaj wyraźnie widać, może być za, ale może być też przeciw Bogu, i to całkowicie świadomie i dobrowolnie. Odrzucenie współwiszącego Jezusa, który nie zrobił żadnej złej rzeczy wobec umierającego złoczyńcy, stanowi Łukaszowy paradoks wolności człowieka zamykającego się na możliwość zbawienia w Jezusie. Nas jednak interesuje nie ten złorzeczący, ale ten, który jako jedyny z ludzi otrzymał zapewnienie Mistrza, że będzie z Nim w raju. Drugi ze złoczyńców, który zdobył się na sprawiedliwość, uznał słuszność ponoszonego przez siebie wyroku. Wypowiada on słowa kontrujące bluźnierstwo wobec Jezusa. Ganiąc współwiszącego łotra, prosi Jezusa: „Jezu, wspomnij na mnie, gdy przyjdziesz do swego królestwa” ('Inбoṽ,

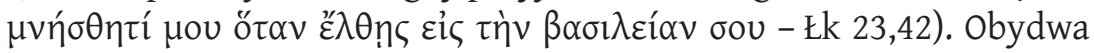

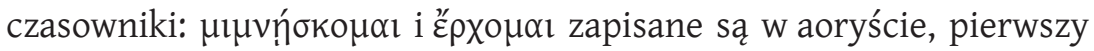
w stronie pasywnej, drugi - aktywnej. Słychać tutaj zatem błaganie umierającego złoczyńcy o zapamiętanie go przez Jezusa, gdy Ten wejdzie do swego królestwa. Na te słowa Chrystus reaguje natychmiast, prowadząc tylko z nim jednym w całej scenie ukrzyżowania dialog: 


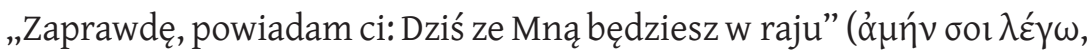

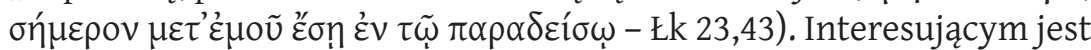

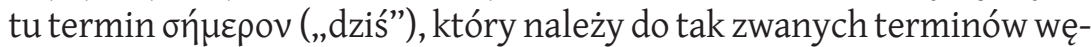
złowych dla św. Łukasza ${ }^{14}$. Dyskusja na jego temat dotyczy problemu, do czego się odnosi: czy to „dzisiejszego” wypowiedzenia się Jezusa (zaprawdę mówię ci dzisiaj), czy też do jego obecności w raju (dzisiaj będziesz ze Mną w raju). Biorąc pod uwagę wszystkie miejsca, w których św. Łukasz używa terminu oń «epov (Łk 2, 11; 4, 21; 5, 26; 12, 28; 13, 32. $33 ; 19,5.9 ; 22,34.61 ; 23,43 ;$ Dz 4, 9; 13, 33; 19, 40; 20, 26; 22, 3; 24, 21; $26,2.29 ; 27,33)$, trzeba przyjąć, że zawsze chodzi o fakt, który dokonuje się w aktualnym dniu - dziś. Zatem rozumienie powyższego zdania odnosić się powinno do „dzisiejszego” wejścia pokutującego złoczyńcy do królestwa Jezusa. Ważną analizę owego czasu zbawienia przybliża H. Langkammer ${ }^{15}$, który nawiązując do postaci św. Szczepana, wyjaśnia możliwość wejścia do szczęścia oglądania Boga zaraz po śmierci. Tylko z tym człowiekiem, który zwraca się z wysokości własnego krzyża do współcierpiącego z nim Jezusa, prowadzi On rozmowę, gwarantując mu zbawienie. To zdanie jest zatem szczególnie ważne w całości siedmiu wypowiedzi Jezusa z krzyża.

Słowa do najukochańszych osób

Na szczególną uwagę zasługują dwie wypowiedzi, które Jezus kieruje do ludzi Mu najbliższych: Matki oraz umiłowanego ucznia. Cała ta scena opisana jest przez naocznego świadka św. Jana. Rozumienie o. H. Langkammera ${ }^{16}$, który wyjaśnia ten obraz, idzie po linii interpretacji mesjańskiej. Jan wymienia najpierw stojące pod krzyżem ( $\pi \alpha \rho \grave{~}$

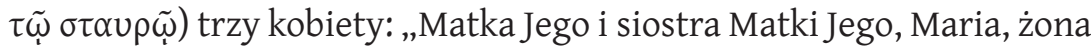
Kleofasa, i Maria Magdalena" (w. 25). Wszystkie one tutaj stoją, co

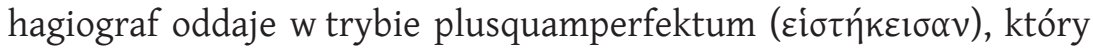

${ }^{14}$ Zob. S. Włodarczyk, Realizacja zbawienia „dziś" w Chrystusie: semeron w soteriologii Łukasza, Lublin 1989. Termin ten pojawia się 11 razy w Ewangelii Łukasza i 9 razy w Dziejach Apostolskich na łączną liczbę 41 wystąpień w Nowym Testamencie - por. R. Morgenthaler, Statistik des neutestamentlichen Wortschatzes, Zürich 1958, s. 140.

${ }^{15}$ Por. H. Langkammer, Passio Domini nostri Jezu Christi..., dz. cyt., s. 108.

${ }^{16}$ Por. tamże, s. 109. 
ma znaczenie trwania w przeszłości ${ }^{17}$. Nie było to zatem tylko chwilowe przystanięcie przy Ukrzyżowanym, ale długotrwałe przebywanie w postawie gotowości, w oczekiwaniu na wydarzenie, co możemy zinterpretować wręcz jako towarzyszenie w drodze umierania Mistrza. Rozumienie „niewiasty” z Rdz 3 przeniesione jest tutaj na Maryję ${ }^{18}$, gdy Jezus wypowiada do Niej zwrot: „Niewiasto, oto syn Twój” (үúval,

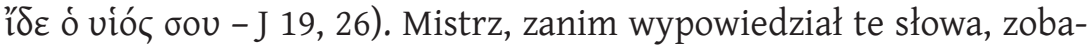

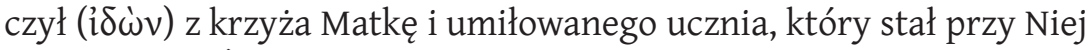
( $\pi \alpha \rho \varepsilon \sigma \tau \tilde{\omega} \tau \alpha)$. Świadomość Jezusa, choć z pewnością nieco przytępiona przez mękę i umieranie, pozostaje wystarczająco ostra w patrzeniu i ocenie dziejących się wydarzeń. Trwanie ucznia i Maryi stojących przy Jego krzyżu owocuje wyjątkowym darem. Najpierw Mistrz mówi do

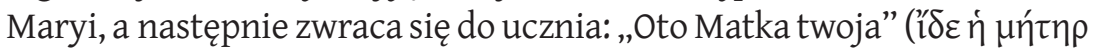
бov - J 19, 27) ${ }^{19}$. W kontekście Księgi Rodzaju, gdzie zapowiedziany jest

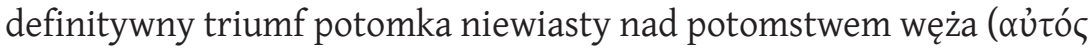

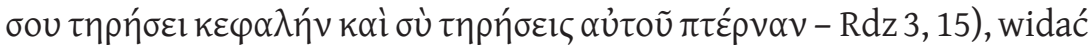
lepiej znaczenie teologiczne tej sceny, którą maluje naoczny świadek. Maryja jako Matka Jezusa ma swój osobisty udział także w Jego triumfie nad grzechem i szatanem, który dokonuje się na krzyżu ${ }^{20}$. Inną ważną myślą teologiczną zauważoną przez o. H. Langkammera ${ }^{21}$ jest fakt, że Jezus daje najpierw Maryi Jana za syna, a następnie mówi, że Maryja jest dla niego matką. Wynika stąd, że dar Maryi jako matki jest bardziej istotny niż sama doczesna troska ucznia o Nią. Wychowując Jezusa, który właśnie w tym momencie na krzyżu dokonuje odkupienia ludzkości, może Ona uformować Jana - nowego syna - na podobnego triumfatora. Może to zrobić także z każdym, który jak Jan stanie razem z Nią przy krzyżu Chrystusa. Ów rys macierzyńskiej miłości, która przenika serce Maryi, ma swoje doskonałe echo w umiłowaniu człowieka przez

${ }^{17}$ Por. Elementy składniowe biblijnego języka greckiego, oprac. A. Paciorek, Kielce 2001, s. 91-92 (Studia Biblica, 2).

${ }^{18}$ Por. J. Kudasiewicz, „I od tej godziny uczeń wzią Ją do siebie” (J 19, 26b), [w:] Pan moim światłem. Księga pamiatkowa dla księdza profesora Jerzego Chmiela w 65. rocznicę urodzin, zebrał i oprac. W. Chrostowski, Warszawa 2000, s. 205-213.

${ }^{19}$ Por. Ewangelia według świętego Jana. Cz. 2: Rozdz. 13-21, wstęp, przekład z oryginału, komentarz S. Mędala, Częstochowa 2010, s. 245.

${ }^{20}$ Por. H. Langkammer, Passio Domini nostri Jezu Christi..., dz. cyt., s. 109.

${ }^{21}$ Por. tamże, s. 110. 
Jej Syna. Jak finalizuje Ewangelista: „, od tej godziny uczeń wziął Ją do

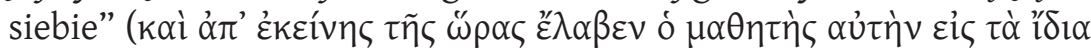

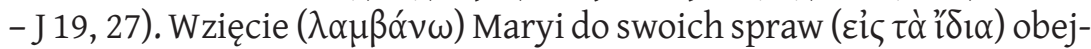
muje wszystko, czym żyje Jan. Od tej pory nie będzie już samotny, ale nierozdzielnie zjednoczony z Matką Jezusa. Tutaj także św. Jan stosuje czas aorystu, który jako nieoznaczony objąć może wszystkie wydarzenia dokonujące się w czasie i przestrzeni jego życia.

Zauważyliśmy w tych dwóch miejscach Ewangelii Łukasza i Jana, że Jezus kieruje swoje słowa do tych ludzi, którzy są z Nim solidarni w cierpieniu. Nie wypowiada On żadnego słowa do wrogów i szyderców: ani do złorzeczącego Mu łotra, ani do przełożonych i tłumu, którzy Mu bluźnili. Jest to jakaś tajemnica słowa Pana, które choć wypowiedziane w sposób czytelny dla wszystkich, znajduje swoje echo w sercach kochających Mistrza. Współczujący Jezusowi złoczyńca zyskuje zapewnienie zbawienia, zaś Maryja i Jan otrzymują zadanie wzajemnej relacji synowsko-macierzyńskiej. Nie wypowiadają oni jednak żadnego słowa do Ukrzyżowanego, jedynie przyjmują Jego polecenie i je wypełniają.

\section{Autodeklaracje Jezusa na krzyżu}

Mamy jeszcze dwa wyrazy, w których Mistrz nie zwraca się ani do Boga Ojca, ani do bliskich Mu ludzi, są to słowa wypowiedziane w sposób niejako obwieszczeniowy, nie wymagający zatem niczyjego potwierdzenia. Znajdują się one w Ewangelii według św. Jana 19, 28 i 30. Scena, która zawiera te dwa słowa Jezusa, rozciąga się pomiędzy aktem darowania Janowi Matki a Jego śmiercią. Hagiograf wprowadza

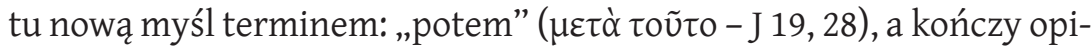

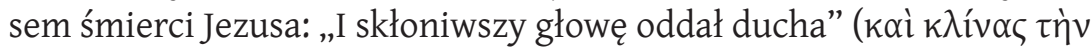

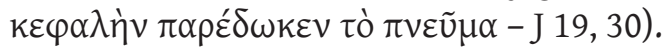

\section{Świadomość zrealizowania misji}

Po obdarowaniu Maryi i Jana relacją synowsko-matczyną do Jezusowej jaźni dociera fakt, że finalizuje się Jego zbawcze dzieło, które wykonał, przychodząc na świat (por. J 1,11). Autor natchniony mówi tu o świadomości Ukrzyżowanego oraz Jego posłuszeństwie Pismu: „Potem Jezus świadom, że już wszystko się dokonało, aby się wypełniło Pismo, rzekł: 


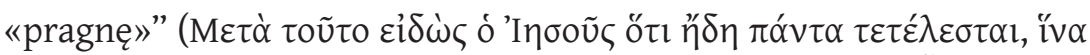

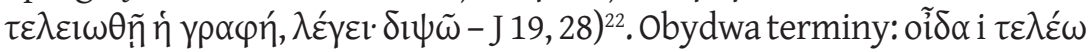
występują w perfektum i odnoszą się do Jezusowej wiedzy, którą aktualnie (na krzyżu) posiada, a która odnosi się do dopełnionego do końca Jego dzieła. Czasownik oĩ $\delta$ a należy do ulubionych słów św. Jana ${ }^{23}$, które pojawia się w J 6, 61. 64; 11, 42; 13, 1.3. 11. 18; 18, 4 w odniesieniu do Jego świadomości. Ważne jest tutaj połączenie przez autora natchnionego zagadnienia Jezusowego poznania, które opiera się na wypełnianiu tego, co napisane jest w Piśmie (ïv $\alpha \varepsilon \lambda \varepsilon l \omega \theta \tilde{\eta} \tilde{\eta} \gamma \rho \alpha \varphi \eta ́)$. Kluczowym jest tutaj także czasownik $\tau \varepsilon \lambda \varepsilon l o ́ \omega$, który wypowiada Jezus w Ewangelii św. Jana w węzłowych momentach: w rozmowie z Samarytanką (J 4, 34), w auto-świadczeniu (J 5, 36), w modlitwie arcykapłańskiej (J 17, 4. 23) oraz właśnie na krzyżu $(\mathrm{J} 19,28)$. Termin ten oznacza wypełnienie, dopełnienie i uczynienie doskonałym ${ }^{24}$.

Piąte według tradycyjnej kolejności słowo Chrystusa z krzyża: ,pragnę” $(\delta i \psi \tilde{\omega}-\mathrm{J} 19,28)$ oznacza zasadniczo naturalne pragnienie człowieka, który chce się napićén. Można jednak mówić tutaj o potrzebie czegoś więcej, zwłaszcza gdy patrzymy na całość wypowiedzi ewangelisty, który mówi o konieczności zrealizowania słów Pisma (ǐv $\alpha \varepsilon \lambda \varepsilon i \omega \theta \tilde{n} \eta \dot{\eta} \gamma \rho \alpha \varphi \eta ́)$. Jezus zatem może odczuwać z jednej strony pragnienie napicia się, ale także i wymóg realizowania słów Bożych zawartych w natchnionych tekstach. Zdaniem H. Langkammera stwierdzenie ewangelisty ma wydźwięk mesjański i jest nawiązaniem do tekstu Psalmu 2 („Gardło moje wyschło jak skorupa, język mój przywarł do podniebienia, w proch śmierci mnie obróciłeś” ${ }^{26}$. Żołnierze oraz św. Jan słyszeli to stwierdzenie Jezusa, ci pierwsi podali Mu na gąbce nieco octu: „Stało tam naczynie pełne octu.

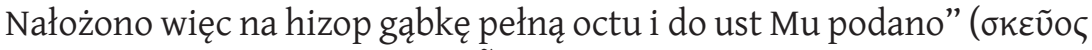

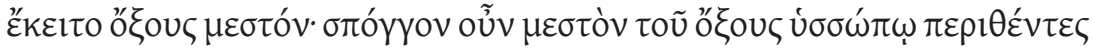

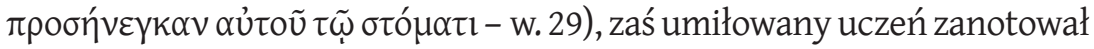

${ }^{22}$ Por. Ewangelia według świętego Jana..., dz. cyt., s. 246.

${ }^{23}$ Por. R. Morgenthaler, Statistik des neutestamentlichen Wortschatzes, dz. cyt., s. 91.

${ }^{24}$ Por. H. Hübner, $\tau \varepsilon \lambda \varepsilon l o ́ \omega$, [w:] Exegetisches Wörterbuch zum Neuen Testament, hrsg. von H. Balz, G. Schneider, t. 3, Stuttgart-Berlin-Köln-Mainz 1983, k. 825-828.

${ }^{25}$ Por. R. Popowski, Wielki słownik greck-polski Nowego Testamentu. Wydanie z petna lokalizacja greckich haset, kluczem polsko-greckim oraz indeksem form czasownikowych, Warszawa 1994, s. 141.

${ }^{26}$ Por. H. Langkammer, Passio Domini nostri Jezu Christi..., dz. cyt., s. 112. 
we własnej pamięci, a następnie w tekście natchnionym tę wypowiedź Mistrza z krzyża. Prośba o napój w przypadku Jezusa, który umiera na krzyżu, nie spotyka się z realizacją ze strony człowieka w postaci uczynków miłosierdzia: „byłem spragniony, a daliście mi pić” (Mt 25, 35), ale z zadaniem dodatkowego cierpienia w postaci gorzkiego napoju: „gdy byłem spragniony, poili mnie octem" (Ps 69 [68], 22). Owo dodatkowe cierpienie, którego doświadczył Chrystus, gdy skosztował gorzkiego napoju, także stanowi wypełnienie się słów psalmów. Dokładnie to, co zostało zapowiedziane, wypełnia się w dziele zbawczym Jezusa.

Wypowiedź podsumowująca wykonane dzieło

Ostatnim z analizowanych słów Jezusa jest wypowiedź: „Wykonało

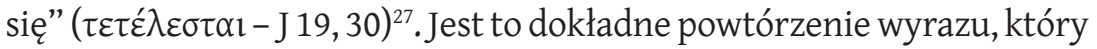
analizowany był nieco wyżej (w. 28). Widzimy zatem pewnego rodzaju zabieg literacki autora natchnionego, który stosując inkluzję, przybliża czytelnikowi obraz wypełniania przez Jezusa planu zbawienia realizowanego z całkowitą świadomością (oĩ $\delta \alpha$ ).

Koniec życia Jezusa zobrazowany jest przez św. Jana w formie czterech czynności połączonych jedną wypowiedzią. Chrystus przyjmuje

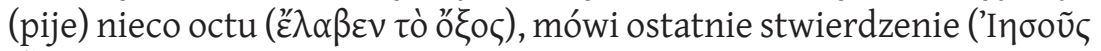

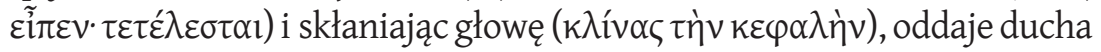

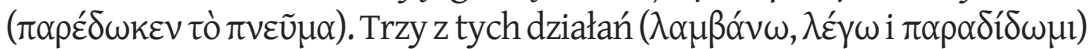
zapisane są w trybie indikatiwu czasu aorystu w stronie aktywnej, co oznacza świadomy i zamierzony gest Mistrza, który także z wysokości krzyża wypełnia dokładnie to, co powinien. Skłonienie głowy ( $k \lambda i ́ v \omega)$ również jest zapisane w aoryście, ale w formie imiesłowu, który dodaje nieco dramatyzmu opisowi, gdyż łączy się on nierozdzielnie ze śmiercią Jezusa - oddaniem ducha. Jeden tylko czasownik posiada formę indikatiwu czasu perfektum w stronie pasywnej - to właśnie ostatnie słowo Chrystusa: $\tau \varepsilon \tau \varepsilon ́ \lambda \varepsilon \sigma \tau \alpha 1$ - „wykonało się” (J 19, 30). Termin ten oznacza całościowe dopełnienie dzieła zbawienia, którego skutki będą trwały już na zawsze. Interesujące jest użycie czasów w tym zdaniu: cztery czynności zapisane w aoryście obejmują stojącą w centrum wypowiedź

${ }^{27}$ Por. Ewangelia według świętego Jana..., dz. cyt., s. 248. 


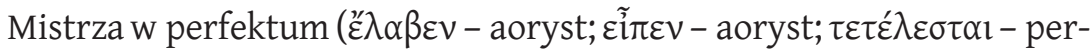
fektum; k $\lambda i ́ v \alpha \varsigma$ - aoryst; $\pi \alpha \rho \varepsilon ́ \delta \omega \kappa \varepsilon v$ - aoryst).

Dwie wypowiedzi Chrystusa z krzyża, które obejmują ostatnie Janowe przesłanie umierającego Mistrza, skupiają się na Jego świadomości oraz wykonywanym dziele zbawienia. Jezus zdaje sobie sprawę z tego, co się z Nim dokonuje, i podejmuje ostatnie czynności w celu wypełnienia słów Pisma. Posłuszeństwo dziełu zbawienia, które Jezus zapoczątkował przez swoje wcielenie, teraz nabiera kształtów doskonałych, gdy umierający Zbawiciel doprowadza wszystko do końca. Pragnienie $(\delta \imath \psi \tilde{\omega})$

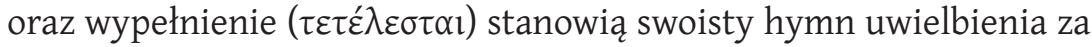
dokonane dzieło.

\section{Wnioski}

Jak można zauważyć, świadomość Jezusa, której dotknęliśmy, analizując Jego ostatnie słowa z krzyża, ogniskowała się wokół Ojca, ludzi, którzy znajdowali się w pobliżu, oraz wokół Jego własnej osoby (samoświadomość). Trzy zdania modlitwy wypowiedziane do Boga mówią czytelnikowi Ewangelii najpierw, że Jezus prosi Ojca o miłosierdzie dla ludzi, następnie że zwraca się do Niego w formie błagalnego psalmu, pokonując barierę pozornego opuszczenia, a wreszcie że w Jego opiekę oddaje na koniec swą duszę.

Słowa do dobrych ludzi, którzy znajdują się w pobliżu krzyża, to nade wszystko zapewnienie skruszonemu złoczyńcy, że osiągnie rychło udział w Jezusowym królestwie, ale także zwroty w stronę Matki i Jana, którzy mają nawzajem wejść w relacje macierzyńsko-synowskie. Relacja rodzinna musi zatem być realizowana $\mathrm{w}$ aktualnym eonie przez ludzi, którzy są bliscy Jezusowi.

Dwa zwroty: „pragnę" oraz „wykonało się" zasadniczo nie są zorientowane do żadnego podmiotu dialogu - ani do Boga, ani do ludzi stojących przy krzyżu. Nazwane zostały tutaj autodeklaracjami Jezusa, który je wypowiedział w sposób ogólny, niejako do samego siebie. Owa relacja Mistrza do siebie, którą tutaj możemy zrozumieć, zawiera także ważne przesłanie teologiczne. Człowiek zbliżający się do granicy doczesności musi odpowiedzieć samemu sobie na pytanie o zrealizowanie planów zbawienia dotyczących jego własnej osoby. 
Siedem zdań Jezusa z krzyża stanowić zatem może wyjątkową lekcję wcielania słów Ewangelii w codzienność ucznia Chrystusa.

Kraków

KS. BOGDAN ZBROJA

\section{Słowa kluczowe}

Jezus, słowa z krzyża, śmierć, krzyż

\section{Summary}

\section{Theology of Jesus' words from the cross}

The article presents a theological message of the last words that Jesus spoke from the height of the cross. Layout content is conveyed in three kinds of Christ's relations: the words addressed to God the Father; the words addressed to the good people standing by the cross; the so-called declarations that the Master had spoken to anyone but uttered them in general.

All these words speak of the Master's love. They express His full awareness of what is being done and of His decision voluntarily taken. Above all, it is revealed in the Lord's statements His obedience to the will of God expressed in the inspired words of the Holy Scriptures. Jesus fulfills all the prophecies of the Old Testament by pronounced words and accomplished works that will become content of the New Testament.

\section{Keywords}

Jesus, words from the cross, death, cross 